\title{
An Initial Development of Smile: A Self-Regulation Based Mobile Mental Health's Application for Adolescents
}

\author{
Dian Veronika Sakti Kaloeti ${ }^{*}$, Annastasia Ediati ${ }^{2}$, W Syafei ${ }^{3}, \mathrm{~J}_{\text {Ariati }}{ }^{4}$, A \\ Prasetijo $^{5}$, A Kurnia ${ }^{6}$, V Tahamata ${ }^{7}$ \\ 1,2,4,7 Family Empowerment Center, Fakultas Psikologi, Universitas Diponegoro, Semarang, Indonesia \\ ${ }^{3}$ Department of Electrical Engineering, Universitas Diponegoro, Semarang, Indonesia \\ ${ }^{5}$ Department of Computer Engineering, Universitas Diponegoro, Semarang, Indonesia \\ ${ }^{6}$ Magister of Psychology, Faculty of Psychology, Universitas Diponegoro, Semarang, Indonesia \\ *Corresponding author. Email: dvs.kaloeti@liive.undip.ac.id
}

\begin{abstract}
Adolescents have shown significantly higher rates of mental health problems than the general public. Research has found the self-regulation is vital in preventing psychopathology. Further, the involvement of digital technology as one health support form is recognized as a promising alternative, especially for this group age. Thus, this study is aimed to develop a self-regulation based mobile application named as SMILE (SelfMonitoring Interactive Learning Evaluation). This paper will present the development process of the various component of the SMILE. This application uses several features like real-time location awareness, online mood check, emotional graphics which will determine tasks that must be done by individuals for 30 days. In the first phase, this application was tested on 255 adolescents $(M=16)$ with 56 percent is a woman. The initial evaluation results were described in one-on-one user testing. Thus, as a monitoring process, the users could track daily emotional conditions and perceived lists of suggested activities. The results suggest that SMILE has the potential to attract adolescents. However, further work is needed to ensure that users remain engaged with the program. Besides, online counseling features can be added, such as the buddy chat feature with a psychologist.
\end{abstract}

Keywords: SMILE, self-regulation, mobile application, mental health, adolescents.

\section{INTRODUCTION}

World Health Organization (WHO) estimates that $10-20 \%$ of the population of children and adolescents in the world are currently experiencing mental health problems and $50 \%$ of them occur before reaching the age of 14 [1]. In Indonesia, $11.6 \%$ of Indonesian adolescents experienced emotional problems [2]. Research shows that mental health disorders that occurred in adulthood derived from problems that befallen in the adolescence stage [3]. Further, this study also stated many as $75 \%$ of mental health problems experienced by individuals, first perform in adolescence [3].

A lot of changes in physical, cognition, emotion and social, as well as the demands of new roles in adolescence included them in a vulnerable population
[4] in term of experiencing various mental health problems, such as the emergence of depression $[5,6]$ and various problematic behaviours. Longitudinal studies conducted in adolescent populations concluded that adolescents experience about 60-90\% of depressive episodes each year [7].

More specifically, the emotional problems of Indonesian adolescents had emerged intensely at the level of junior high school, with higher anxiety and depression in girls compared to boys [5]. Similarly, other study with university students found that individuals with childhood unfinished negative experiences would develop clinical symptoms such as depression and anxiety [8]. They will also more fragile to life stressors in terms of reactions and coping. Then this phase is one of the crucial times for 
prevention and early treatment of mental health problems.

On the other side the rapid growth of digital technology adopted very-well by this generation such as the uses of internet and digital media. In 2017, Indonesia had $54.58 \%$ internet users and increased to $64.8 \%$ in 2018 of the total population and about $91 \%$ of internet users are adolescence [9]. Then, it is estimated using digital applications as part of psychological intervention has high possibility to reach adolescents participation [10]. The involvement of digital technology becomes important when the target of treatment is adolescents because the level of familiarity, readiness, and frequency of use of technology in interacting is quite high in the adolescent phase $[10,11]$. Interventions using mobile phones, including the application of smartphones (smartphones) to improve mental health, are among the relatively new approaches. The study of the use of cellphone technology, in the beginning, was carried out in Germany and England. In Germany, Bauer uses messages on mobile phones for aftercare for bulimia nervosa patients [12]. Then in England, Franklin in his study used a program called "Sweet Talk", a program that sent messages of support about intensive use of insulin for adolescents with diabetes.

The ability to overcome problems is very influential on adjustment and becomes one of the predictors of the emergence of depression [13]. In addition to depression, anxiety is also one of the conditions experienced by adolescents [14]. Strengthened by this condition, studies show that the inability to monitor, evaluate and modify emotions and behaviour when facing change will cause anxiety [15]. Anxious adolescents have difficulty managing emotions and become less confident in their abilities [16]. When they are able to control and regulate themselves, they will achieve resilient status [17,18]. Resilient individuals will be able to adapt and achieve optimal development. Further, adolescents who succeeded in setting and determining goals and were able to evaluate errors had higher resilience compared to adolescents who were unable to do it [19]. Other research also found that individuals who are able to regulate themselves will have the opportunity to achieve success in the academic world and non-academics [20]. Also, self-regulation is associated with optimum mental health status [2123]. Further, a digital-based psychological intervention is needed that is compatible with the characteristics of adolescents and adaptive to the times. The technology created can be accessed anytime and anywhere, is personal and can be used with the desired media (mobile devices, computers).

This paper will present the development process of the various component of the SMILE. This research uses self-regulation theory as the basis for creating intervention and innovation, called SMILE (Self-Monitoring Interactive Learning Evaluation). Self-regulation is an individual's ability to achieve goals, namely planning strategies, evaluating and modifying behaviour, avoiding influences from the environment that can interfere with achieving goals [24].

\section{METHOD}

\subsection{Participants}

This paper used Convenience sampling. In the first phase, this application was tested on 255 adolescents in several schools in Indonesia $(\mathrm{M}=16)$.

\subsection{SMILE Features}

Self-regulation process carried out by individuals in several ways, which will be loaded as a feature in the SMILE application, namely task, self-monitoring, interactive, learning, evaluation and android support. In the task features, SMILE has several advantages, namely real-time location awareness, online mood check, and emotional graphics which will determine tasks that must be done by individuals for 30 days. Self-monitoring activities that are occupied on cellphones will help to reduce or prevent symptoms of mental health disorders. Self-monitoring is a way to get realistic targets and also evaluate behaviour in achieving goals. Self-monitoring in the form of daily notes about activities, emotional conditions, and response or problem solving when facing unpleasant events. The interactive feature facilitates communication between fellow users. This will serve as peer support and a means of getting feedback, to develop and strengthen the targeting behaviour. In learning process, this application will present visual and audio psychoeducation articles on ways that can be done to improve self-regulation skills. Psychoeducation serves as a learning tool which can then be practiced daily or when dealing with unpleasant stressors. In evaluation process, the ability to compare current behaviour conditions with targets to be achieved, and to know the extent to which the desired behavioural progress in accordance with the target is one of the self-regulation skills [25]. This 
feature will send a reminder about the target, the schedule that has been determined by the individual application user. The SMILE application can be download at google play store and supported on Android OS

on https://play.google.com/store/apps/details?id=com.ap plication.smile.smile (figure 1).

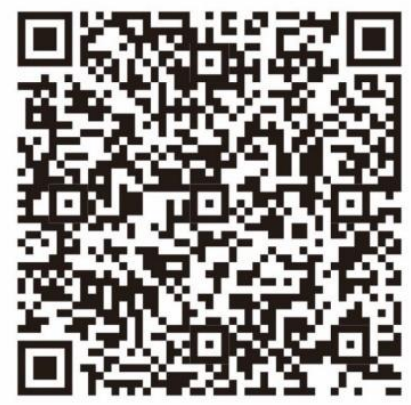

Figure 1 Smile Barcode

\subsection{SMILE Procedures}

The use of the smile application is carried out in three stages namely installed the application, do daily activity challenges, and fill mood check (figure 2). At the first stage, participants installed the application and filled out a screening of psychological conditions (predisposition to depression, stress and anxiety). The Depression Anxiety Stress Scales (DASS-21) was designed to measure emotional distress in three subcategories of depression (e.g., I felt I had nothing to look forward to), anxiety (e.g., I experienced trembling), and stress (e.g., I found it difficult to relax) [26]. It was a self-reporting questionnaire with 21 items (seven items for each category) based on a four-point rating scale. Participants were asked to rate how many of each of the items (in the form of statements) applied to them over the past week. To calculate comparable scores with full DASS, each seven-item scale was multiplied by two. The higher the score, the more severe the emotional distress was. The DASS-21 has been found to have good psychometric properties, with all 3 scales demonstrating high internal consistency. The DASS21 is freely available in the public domain and has been translated into approximately 30 different languages [27]. Subsequently, at the second stage, the screening results obtained will determine the daily activity for 30 days that needs to be done. Finally, at the at the third stage participants will receive daily reminders about the activities carried out, and fill in a mood check.

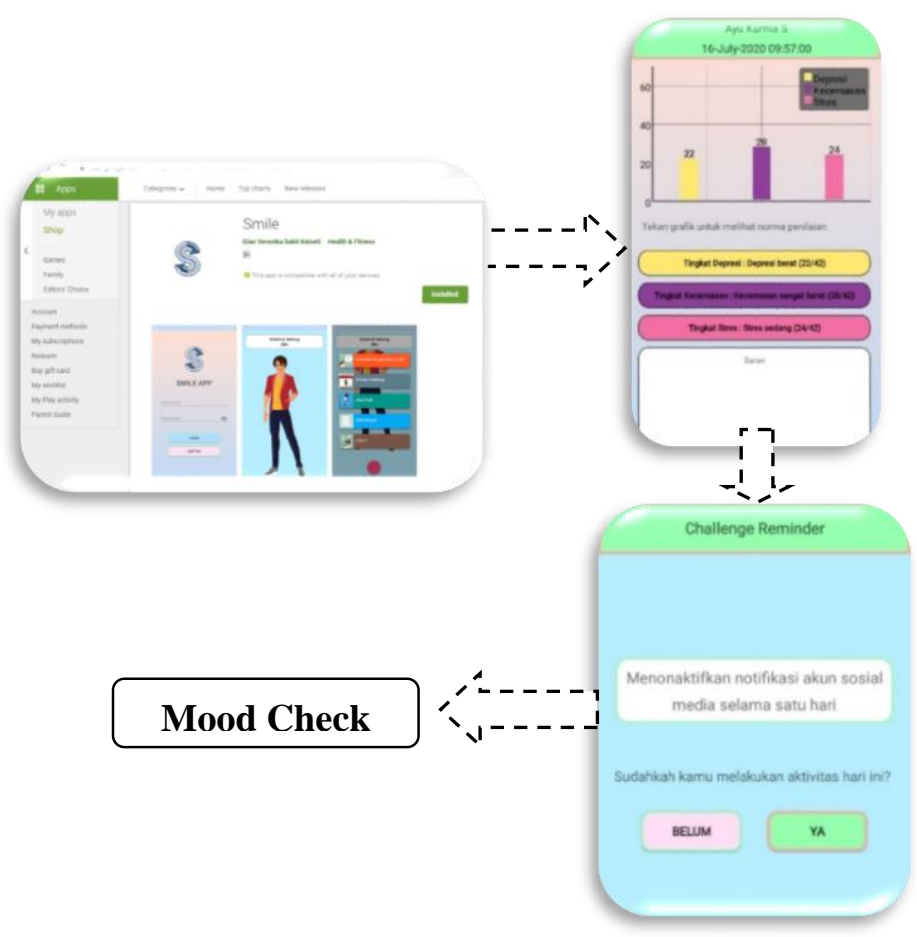

Figure 2 Smile Procedure

\section{RESULT}

\subsection{Participants' Characteristics}

Based on participant's characteristics data shows that a total of 255 participant's responses were collected, with more than half are woman (56\%) and most of the participant's age was between 16-18 year $(50,58 \%)$ (Table 1). On the other hand, The average ethnics of participants from Javanese $(94,11 \%)$ and $38,43 \%$ participants with undergraduate student's parental educational history.

Table 1. Participants' characteristics $(\mathrm{N}=255)$

\begin{tabular}{|l|c|c|}
\hline \multicolumn{1}{|c|}{ Characteristics } & f & \% \\
\hline Gender & 112 & 43,92 \\
\hline Man & 143 & 56,07 \\
\hline Woman & & \\
\hline Age & 14 & 5,49 \\
\hline $10-12$ & 99 & 38,82 \\
\hline $13-15$ & &
\end{tabular}




\begin{tabular}{|c|c|c|}
\hline $16-18$ & 129 & 50,58 \\
\hline $19-23$ & 13 & 5,09 \\
\hline \multicolumn{3}{|l|}{ Etnic } \\
\hline Javaness & 240 & 94,11 \\
\hline Sunda & 2 & 0,78 \\
\hline Melayu & 4 & 1,56 \\
\hline Chinese & 4 & 1,56 \\
\hline $\begin{array}{l}\text { Others (Lampung, } \\
\text { Makassar, Minang, } \\
\text { Batak) }\end{array}$ & 5 & 1,96 \\
\hline \multicolumn{3}{|l|}{ Education } \\
\hline Junior High School & 78 & 30,5 \\
\hline Senior High School & 171 & 67,05 \\
\hline Undergraduated Student & 6 & 2,35 \\
\hline \multicolumn{3}{|c|}{ Parental Educational History } \\
\hline Elementary School & 35 & 13,72 \\
\hline Junior High School & 8 & 3,13 \\
\hline Senior High School & 53 & 20,78 \\
\hline Undergraduated Student & 98 & 38,43 \\
\hline Master Student & 61 & 23,92 \\
\hline \multicolumn{3}{|l|}{ Family Income (Rupiah) } \\
\hline$<1.000 .000$ & 110 & 43,13 \\
\hline $1.000 .000-3.000 .000$ & 54 & 21,17 \\
\hline$>3.000 .000$ & 91 & 35,68 \\
\hline
\end{tabular}

\section{SMILE initial development}

The results suggest that SMILE has the potential to attract adolescents. The SMILE application is designed to be simple and easy to use. Only two users are involved, e.g. admin and user. Admin has the responsibility to manage the user and database. User is the participants who use the application. The user menu structure is the menus contained on the page that are available to the user. Users are required to $\log$ in first before entering the main menu (Figure 3).

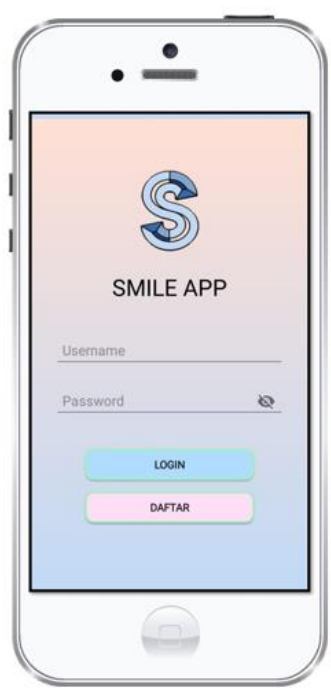

Figure 3. Smile application home page

\section{Home Page}

This page is a registration page. On this page, users are asked to fill in their identity, namely name, age, and education level.

\section{User Menu}

This page appears when the user presses a button available on the home page. This page provides several smile features that can be used, namely the emotion recognition feature, bio, and others

\section{Admin Menu}

Admin can manage user applications. on this page, there are several submenus, namely manage user, manage history, demographic data, dass-21 data, and logout. Admin also is able to view the Demographic data which presents the profile of all users who deals with this application. This application uses waterfall method which consists of system analysis, design, implementation, and testing is chosen to develop this application software. It utilizes to facilitate psychologists in measuring the psychological conditions in terms of depression, stress and anxiety. 
This method uses a systematic and sequential approach in the development of software. To understand the function and behaviour of this application, analysis of information and behaviour is required and refers to the stage of system requirements analysis. Table 2 shows an analysis of system user requirements.

Table 2. Analysis of system user requirements

\begin{tabular}{|l|l|l|}
\hline No & Actor & \multicolumn{1}{|c|}{ Description } \\
\hline 1 & Admin & $\begin{array}{l}\text { Admin has access rights to manage } \\
\text { user data manage questionnaire } \\
\text { history data, view demographic data, } \\
\text { and view DASS-21 data. Admin can } \\
\text { view, change, and delete user data } \\
\text { from the application. Admin can view } \\
\text { and delete the user questionnaire } \\
\text { history from the application. Admin } \\
\text { can view demographic data containing } \\
\text { statistical data from user applications } \\
\text { based on age, gender, ethnicity, the } \\
\text { current level of education, parental } \\
\text { education, and parental income. Also, } \\
\text { admin can see the results data from } \\
\text { DASS-21 in the form of the number of } \\
\text { levels of depression, anxiety, and } \\
\text { stress that have been generated by the } \\
\text { user der he }\end{array}$ \\
\hline 2 & User & $\begin{array}{l}\text { Users have access rights to retrieve } \\
\text { questionnaires, see the results of } \\
\text { questionnaires, see profiles of personal } \\
\text { identity data, see the history of } \\
\text { questionnaires that have been taken, } \\
\text { and delete the history of } \\
\text { questionnaires that have been taken. }\end{array}$ \\
\hline
\end{tabular}

\section{Admin portal}

There are several steps that the admin can do to access the smile application. First, the admin logs in by filling in the identity in the form of name, email address and age. After success, there is a menu for managing users, managing history, user demographic data, and user emotional condition data. Admin portal is shown in figure 4. Admins can also delete user accounts on the delete user menu.

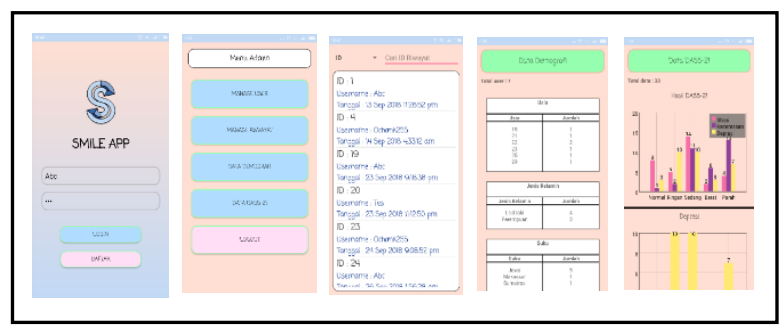

Figure 4. Admin Portal

\section{User portal}

There are several activities carried out by users. the first activity is to $\log$ in. Then, users filled out the DSS-21 questionnaire. After receiving information on the results of emotional conditions, users accept challenges that can be done every day to overcome emotional problems at hand. in addition, users can read mental health educational articles as well as podcasts that can help improve mental health.

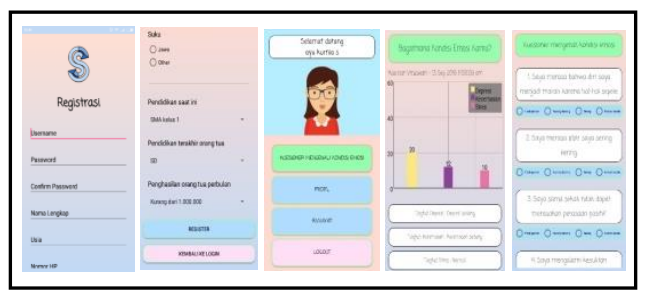

Figure 5. User Portal

\subsection{Discussion}

Mobile interventions can help to build mentally and physically healthy habits because they can be repeated across time, and specifically targeted to high-risk time periods (e.g. after a meal for a smoker). They can also be individually tailored based on characteristics of participants (e.g. name, gender, age, etc). Moreover, the fact that mobile 
interventions are applied within everyday contexts may help people to generalize these behaviours across a variety of real-life settings (e.g. work, school, home, leisure). Mobile-based technologies offer a number of advantages for interventions specifically focused on mental health. For example, they have the potential to improve the accessibility of treatment and increase adherence to medication [28]. There is also the potential for researchers or clinicians to track the progress of treatment via realtime data collection. Moreover, there is potential for personalization, which may increase motivation to continue treatment programs. Thus, the potential for mobile-based interventions in mental health has been underutilized.

\subsection{Conclusion}

SMILE application has the potential to attract adolescents. The SMILE application is designed to be simple and easy to use. However, further work is needed to ensure that users remain engaged with the program. Besides, online counseling features can be added, such as the buddy chat feature with a psychologist.

\section{ACKNOWLEDGMENTS}

This work was supported by DRPM, Ministry of Research, Technology, and Higher Education of the Republic of Indonesia through the LPPM UNDIP under the Applied Research Scheme (Grant Number 101-172/UN7.P4.3/PP/2018). The authors also thanked to 255 participating adolescents in this research.

\section{REFERENCES}

[1] World Health Organization. Mental health status of adolescents in South-East Asia: Evidence for action. New Delhi: World Health Organization. Regional Office for South-East Asia. 2017

[2] Kemenkes RI. Riset Kesehatan Dasar; RISKESDAS. Jakarta: Balitbang Kemenkes RI. 2013

[3] R.C. Kessler, P. Berglund, O, Demler, R. Jin, K.R. Merikangas, E.E. Walters. Lifetime prevalence and age-onset distributions of DSM-
IV disorders in the National Comorbidity Survey Replication. Arch Gen Psychiatry. 62(6) (2005) 593-602. DOI: 10.1001/archpsyc.62.6.593

[4] D. Papalia, R.D. Feldman. Experience human development 12th edition. Indonesia: McGrawHill Education. 2014

[5] A. Ediati Profil problem emosi/perilaku pada remaja pelajar SMP-SMA di Kota Semarang. J. Psikol. Undip. 14(2) (2015) 190-198

[6] E.J. Costello, H. Egger, A. Angold. 10-year research update review: The epidemiology of child and adolescent psychiatric disorders: I. Methods and public health burden. J Am Acad Child Adolesc Psychiatry. 44 (2005) 972-986.

[7] V. Dunn, I.M. Goodyer. Longitudinal investigation into childhood-and adolescenceonset depression: Psychiatric outcome in early adulthood. Br. J. Psychiatry. 118(3) (2006) 216222. DOI: https://doi.org/10.1192/bjp.188.3.216.

[8] D.V.S. Kaloeti, A. Rahmandani, H, Sakti. S. Salma, S. Suparno, S. Hanafi. Effect of childhood adversity experiences, psychological distress, and resilience on depressive symptoms among Indonesian university students. Int $\mathrm{J}$ Adolesc Youth. 1(1) (2018) DOI: 10.1080/02673843.2018.1485584

[9] APJII [Asosiasi Penyedia Jasa Internet Indonesia (Indonesian Internet Service Providers Association)]. Laporan Survei: Penetrasi \& Profil Perilaku Pengguna Interneet Indonesia. Bul APJII. 2019 Edisi 40 (Mei): 1-6. Retrieved from https://apjii.or.id/survei

[10] S.P. Walsh, K.M. White, R.M. Young. The phone connection: A qualitative exploration of how belongingness and social identification relate to mobile phone use amongst Australian youth. J Community Appl Soc Psychol. 2008; 19(3). DOI: 10.1002/casp.983.

[11] Y.D. Kauer, S.C. Reid, L. Sanci, G.C. Patton. Investigating the utility of mobile phones for collecting data about adolescent alcohol use and related mood, stress and coping behaviours: Lessons and recommendations. Drug Alcohol 
Rev. 28(1) (2009) 25-30. DOI: 10.1111/j.14653362.2008.00002.x.

[12] S. Bauer, R. Percevic, E. Okon, R. Meermann, H. Kordy. Use of text messaging in the aftercare of patients with bulimia nervosa. Eur Eat Disord Rev. 11(3) (2003) 279-290. DOI: 10.1002/erv.521.

[13] Jorm AF, Griffiths KM, Christensen H, Parslow RA, Rogers B. Actions taken to cope with depression at different levels of severity: A community survey. Psychol. Med. 34(2) (2004) 293-299. DOI: 10.1017/S003329170300895X.

[14] M. Burstein, H. Jian-Ping, K. Gabriela, A. MarieAlbano, A. Shelli, K. Merikangas. Social Phobia and Subtypes in the National Comorbidity Survey-Adolescent Supplement: Prevalence, Correlates, and Comorbidity. J Am Acad Child Adolesc Psychiatry. 50(9) (2011) 870-880. DOI: 10.1016/j.jaac.2011.06.005.

[15] S.G. Hofmann, A.T. Sawyer, A. Fang, A. Asnaani. Emotion regulation model of mood and anxiety disorders. Depress. Anxiety. 29(5) (2012) 409-416. DOI: 10.1002/da.21888.

[16] A. Kranzler, J.F. Young, B.L. Hankin, J.R. Abela, M.J. Elias, E.A. Selby. Emotional Awareness: A Transdiagnostic Predictor of Depression and Anxiety for Children and Adolescents. J. Clin. Child Adolesc. 45(3) (2016) 262-269. DOI: 10.1080/15374416.2014.987379.

[17] W. Hofmann, M. Luhmann, R.R. Fisher, K.D. Vohs, R.F. Baumeister. Yes, but are they happy? effects of trait self-control on affective well-being and life satisfaction. J Pers. 82(4) (2013) 265-277. DOI: 10.1111/jopy.12050.

[18] E.E. Werner, J.L. Johnson. The Role of Caring Adults in the Lives of Children of Alcoholics. Subst Use Misuse. 39(5) (2004) 699-720. DOI: 10.1081/JA-120034012.

[19] R. Artuch-Garde, M.D. González-Torres, I.D. Fuente, M.M. Vera, M. Fernández-Cabezas, M. López-García. Relationship between Resilience and Self-regulation: A Study of Spanish Youth at Risk of Social Exclusion. Front. Psychol. 2017; $\quad$ 8: $612 . \quad$ DOI: https://doi.org/10.3389/fpsyg.2017.00612.
[20] O.I. Sabela, J. Ariati J, I. Setyawan. Ketangguhan mahasiawa yang berwirausaha: Studi kasus. J Psikol. Undip. 13(2) (2014) 170189.

[21] L. Campbell-Sills, D.H. Barlow. Acceptability and suppression of negative emotion in anxiety and mood disorders. Emotion. 6(4) (2006) 587595. DOI: $10.1037 / 1528-3542.6 .4 .587$.

[22] S. Rude, C. McCarthy. Brief report: Emotional functioning in depression and depressionvulnerable college students. Cogn Emot. 17(3) (2003) 799-806. DOI: $10.1080 / 02699930302283$.

[23] T.L. Webb, E. Miles, P. Sheeran. Dealing with feeling: A meta-analysis of the effectiveness of strategies derived from the process model of emotion regulation. Psychol Bull. 138(4) (2012) 775-808. DOI: 10.1037/a0027600.

[24] C. Daniel, L.A. Pervin. Kepribadian: Teori dan penelitian. Jakarta: Salemba Empat. 2010

[25] G.A.R. Febbraro, G.A. Clum. Self-regulation theory and self-help therapies. In P.L. Watkins $\&$ G.A. Clum. Handbook of self -help therapies. New York: Routledge. 2008

[26] S.H. Lovibond, P.F. Lovibond. Manual for the Depression Anxiety Stress Scales. (2nd. Ed.), Psychology Foundation, Sydney. 1995.

[27] J.R. Crawford, P.H. Garthwaite, C.J. Lawrie. A convenient method of obtaining percentile norms and accompanying interval estimates for self-report mood scales (DASS, DASS-21, HADS, PANAS, and SAD). Br J Clin Psychol. 2009; 48(2):163-180.

[28] E. Granholm, D. Ben-Zeev, P.C. Link, K.R. Bradshaw, J.L. Holden. Mobile Assessment and Treatment for Schizophrenia (MATS): A pilot trial of an interactive text-messaging intervention form medication adherence, socialization, and auditory hallucinations. Schizophr. Bull. 38(3) (2012) 414-425. DOI: $10.1093 / \mathrm{schbul} / \mathrm{sbr} 155$. 